\title{
Leadership development: making a difference in unfavourable circumstances
}

\author{
Martin Clarke, General Management Development Programmes Group, Cranfield School of \\ Management, Cranfield, UK \\ Catherine Bailey, General Management Development Programmes Group, Cranfield School \\ of Management, Cranfield, UK \\ Joanna Burr, General Management Development Programmes Group, Cranfield School of \\ Management, Cranfield, UK
}

\section{Corresponding author}

Catherine Bailey can be contacted at: c.bailey@cranfield.ac.uk

\begin{abstract}
Purpose - This paper is derived from a two-year study that sought to provide a critical understanding of the current state of business leadership development (BLD) and to identify directions for innovative future practice. The second of two companion papers, this contribution aims to investigate the influence of unfavourable competing agendas on BLD and how human resource development (HRD) professionals can work effectively within such circumstances.
\end{abstract}

Design/methodological approach - The paper analyses three case studies of HRD managers who made significant contributions to their organisation's BLD despite unfavourable political circumstances. These individuals were selected from a population of 190 managers from the first phase of the overall study.

Findings - The cases highlight the centrality of political activity to effective BLD design and implementation that is subject to unfavourable circumstances. In particular, the individuals demonstrated the importance of relationship management, challenge and critique and of building change from the bottom up, irrespective of direct senior management support.

Practical implications - The cases shed light on the types of behaviour that may enable HRD professionals to make an effective contribution to BLD, even when there is little formal senior management support. Questions are provided to encourage personal learning and debate about the role and value of HR in the enactment of BLD.

Originality/value - The findings indicate that much best practice advice on leadership development needs to be tempered with an acknowledgement of the degree to which it is subject to competing interests and postulates that constructive political action may be a legitimate activity for HRD managers despite mainstream unitarist advice.

Article Type: Case study

Keyword(s): Leadership development; Organizational politics; Organizational change. 
There is ample advice on offer to practitioners attempting to identify and promote leadership development within their organisation. This typically centres on the importance of aligning development with business strategy, gaining high level support, and forging a partnership between human resources (HR) and line managers (Fulmer and Wagner, 1999; see also Zenger et al., 2000; Ready and Conger, 2003). Whilst some research into the role of HR in employee development reflects a positive contribution (Gibb, 2001; Murphy and Southey, 2003), both anecdotal evidence and academic research (Conger and Xin, 2000; Gratton et al., 1999; Truss, 2001) indicate that achieving these conditions and approaches in practice can be problematic. Using a case study approach, this paper seeks to illuminate this gap between theory and practice by analysing the activities of human resources/management development (HR/MD) professionals working in circumstances that do not reflect these high levels of organisational support for leadership development.

Criticisms of management development practice point to; a frequent lack of strategic integration between HR, management development and the business (Mabey and Thomson, 2000; House and Aditya, 1997; Mabey, 2005); poor evaluation of outcomes (Axel, 1999; Cairns, 1997; Santos and Stuart, 2003); the over use of competency frameworks (Hayes et al., 2000; Conger and Xin, 2000); and concerns about HR/MD managers being able to act as good role models, to influence the business and to take a strategic overview (Guest and King, 2004; Meldrum and Atkinson, 1998; Tate, 2004). Perhaps not surprisingly therefore, in a recent CIPD survey of training managers (Sung and Quinn, 2005), only 8 per cent of respondents rated their leadership development as "very effective". So, is best practice advice fundamentally flawed or is it simply in need of refinement or contextualisation?

This question marked the starting point of a research project to provide a critical understanding of the current state of business leadership development (BLD) and to identify directions for innovative future practice. Our research deliberately focussed on the role of business leadership in order to more readily identify the relationship between leadership development and business performance. The research results of Phase One, based on a sample of 103 managers in 20 UK organisations, are reported elsewhere (Clarke et al., 2004; Clarke and Bailey, 2002) but in summary revealed the extent to which BLD in practice is an unfocussed and extremely diffuse activity. It was also not evaluated well and poorly aligned to business needs. This malaise was the product of four interrelated factors: aligning BLD strategy to HR best practice rather than medium/long-term business needs, lack of senior management vision for BLD, poor quality HR thinking, and differing agendas and organisational politics; that when combined, created "Catch 22 " situations where successful development is fundamentally undermined by mutually limiting constraints. For example, attempts to make better organisational use of BLD are restricted when senior managers have a limited view of its value, a view that is only likely to change through their own experience of BLD.

In response to this widespread lack of coherence of approach, phase two of the research programme sought to understand how those involved in BLD made sense of their situation and came to decisions about strategy and action, that enabled them to overcome this complex set of unfavourable circumstances. This involved a large-scale international survey of views and BLD practice and the qualitative analysis of cases of successful and innovative BLD activity derived from phase one data. A case methodology was selected on the grounds that this research method most readily lent itself to the inductive aspect of phase two and is particularly useful where theory development is weak (Harrison, 2002). 
These cases form the basis of this paper. A companion paper (Bailey and Clarke, 2008) explores the first two of the four barriers to effective BLD and focuses on the issue of achieving business relevance in BLD and the quality of HR/MD strategy formulation. This second paper investigates the final two barriers that are concerned with the influence of competing political agendas on BLD and how Human resource development (HRD) professionals work within this context. In both of these papers we adopt a critical realist perspective (Bhaskar, 1974) in which organisation, structure culture and strategy are seen to co-exist but act independently of each other (Chia, 2002; Fairclough, 2005). This perspective readily lends itself to analysing the relations between the unobservable, casual or generative mechanisms (of effective BLD) and their observable effects (Chia, 2002; Blaikie, 1993; Partington, 2002). In particular, this perspective encourages speculation about "plausible, understandable cognitive processes" (Partington, 2002, p. 141) that mediate between the recognition of unfavourable organisational circumstances and the resulting action. Based on this perspective we present two contributions. First, we draw some tentative conclusions about the broad personal dispositions, behaviours and activities that enable HRD professionals to positively influence the design and delivery of BLD in their organisation in difficult circumstances. Second, following Buchanan (1999), we also present these qualitative cases as vehicles for personal learning; written as potential "classroom" cases we hope that they can be used to stimulate debate about the role of HR/professionals in leading change in BLD. Practical guidance for HRD professionals struggling to make a difference in similar situations is provided and potential areas for further research are identified.

\section{Power and politics in HRD}

The organisation case analysis in the companion paper (Bailey and Clarke, 2008) highlights the importance of five factors in shaping successful BLD strategy; linking BLD strategy to business need, linking development method to business need, clarity and communication about the role of management development, taking a discriminating approach toward evaluation and the criticality of individual leadership. This final factor is of particular interest to HRD professionals seeking to generate and implement BLD strategy. BLD has long been considered a traditional remit of the HRD function, yet as our initial research revealed, many HRD professionals struggle to make a real impact because they get caught in "Catch 22" situations where development is fundamentally undermined by mutually limiting constraints. This appears to contrast with generalised accounts of best practice leadership development where senior management ownership and accountability are attained but where insufficient reference is made to how this is practically achieved (see for example, Ready and Conger, 2003).

The companion paper also indicates, in line with the view of others (Sheehan, 2005; Novicevic and Harvey, 2004) that political savvy might well be a significant factor in how those leading leadership development are able to make a difference in such unfavourable circumstances. There is now a growing body of literature about the constructive role of politics in management and leadership (Buchanan and Badham, 1999; Butcher and Clarke, 2002; Ammeter et al., 2002). From this perspective, politics is seen as a valuable process for resolving the inevitable differences of organisation life (Butcher and Clarke, 2002). However, as yet there has been insufficient attention given to the enactment of micro politics in the every day work of HRM professionals (Ferris and Judge, 1991; Galang and Ferris, 1997) and in leadership in general (House and Aditya, 1997; Ray et al., 2004). There are two possible explanations for this. 
First, politics have traditionally been viewed with some ambivalence by managers regardless of functional perspective (see Buchanan and Badham, 1999, for a comprehensive literature review of this issue). For example, organisation politics has attracted widely divergent opinions, ranging from its description as "game playing, snide, them and us, aggressive, sabotaging, negative, blaming, win-lose, withholding, non-co-operative behaviour" (Stone, 1997, p. 1) to "a disarmingly charming and engaging manner that inspires confidence, trust, sincerity and genuineness" (Perrewe et al., 2000, p. 117). Faced with this level of contradiction it is understandable if HR managers view politics with some scepticism. We were therefore interested to identify the extent to which political considerations were reflected in the activity of HRD professionals, who, working in conditions unfavourable to coherent BLD, were nevertheless able to make progress.

A further explanation might lie in the fact that HR norms and values have traditionally been firmly rooted in a unitary mindset (Gratton et al., 1999; Caldwell, 2003; Guest and King, 2004) and the acceptance of a plurality of interests implicit in political activity runs counter to this unitary approach. This is seen to affect both the output of management learning and the basis on which HR/MD interventions are constructed. For Burgoyne and Jackson (1997), a unitary perspective oversimplifies the process of management learning by excluding many of the cognitive, symbolic and political aspects of management development activity. This has led to the situation where too many management development initiatives have failed to make an impact because they have focussed on an idealised notion of what should be happening rather than factoring in the complexities of the people involved. Perhaps more fundamentally, such a unitary perspective also tends to emphasis values of "strategic fit" and "best practice" and discourages consideration of the value of a wider range of resources that can be utilised by HR managers to affect change (Francis, 2002). These factors may have combined to make the discussion of political behaviour in an HR context an illegitimate issue for practitioners. For example, in Murphy and Southey's (2003) research into the role of HR practitioners on the introduction of innovative practice, political influence was not judged to be significant.

In phase one of our research, however, political activity was evident at all levels of BLD activity. BLD was hotly contested territory because it reflected fundamental issues of organisation control (Coopey, 1995; Francis, 2002). For example, managers often accounted for the lack of any coherent approach to BLD through observations such as:

The organization is too fragmented with autonomous factions, often in competition with each other and hence currently no integrated strategy (John, Drinkco).

People try to grow others in their own image, and protect their own patch. They do not want to risk losing good people through development activities like job rotation (James, Pharmaco).

Truss (2001) suggests that the changing nature of organisation boundaries and the increasing significance of such informal organisational predispositions have rendered the traditional functional approach to HR redundant. Mabey (2002) argues for more investigation into how knowledge is created and diffused without assuming corporate and individual interests are aligned. In a similar vein, Skinner and Mabey (1997) note the need for more research into the realities of HR directors and middle managers at all stages of the organisation change process. 
To what extent then, do HRD professionals engage in political activity counter to the professions traditional unitarist viewpoint? If they do, what does this look like in practice? There has been much discussion in the human resource management (HRM) literature about a gap between the reality of HRM activity and its rhetorical underpinnings (Legge, 1995; Francis, 2002), in which mangers use HRM rhetoric to engage in the persuasive construction of an organisational reality that is used to subvert individual organisational experience. Conventional rhetoric regarding HR and leadership development tends to reflect the value of partnerships (Fulmer and Wagner, 1999) and shared ownership (Ready and Conger, 2003) between HR and line managers striving towards a single unifying goal (Caldwell, 2003). In contrast individual experience is often reported in terms of political behaviour characterised by covert action, conflict, negotiation and divergent agendas (Butcher and Clarke, 2001).

Based on the above analysis we propose that in unfavourable circumstances, those HRD professionals who reflect a leadership orientation are likely to adopt political behaviours in order to successfully implement BLD strategy. Unfavourable circumstances are defined here as situations in which there was evidence of confusion about the role of BLD or that there was a lack of an agreed strategic priority toward BLD. We define political behaviour as "those deliberate efforts made by individuals and groups in organizations to use power in the pursuit of their own particular interests" (Butcher and Clarke, 2001, p. 18). Power in this regard is viewed as situational and relational, derived from a plurality of sources and widely distributed, rather than simply a commodity possessed by a small number of individuals or groups (Burgoyne and Jackson, 1997; Swan et al., 2002).

\section{Case methodology}

Our aim in constructing the cases presented here was to select a small number of examples, not on the basis of representativeness, but on their potential for learning (Buchanan, 1999). Rather than seeking generalisability at the level of populations, it was intended that the qualitative data would facilitate an explanation about the structure, process and drivers of individual action in these circumstances. Our sample was taken from the original phase one population of 103 managers; the companion paper (Bailey and Clarke, 2008) details the research methodology used to generate this data. A total of $17 \mathrm{HR} / \mathrm{HRD}$ managers were interviewed in this sample.

In phase one of the research we identified a number of leadership capabilities that were considered critical for future-oriented leadership (see Table I). This list of future leadership capabilities was used as the basis for identifying those managers who demonstrated some level of leadership orientation.

Individuals were selected on the basis that their interview data reflected at least two thirds of these capabilities. This percentage was chosen on the assumption that "perfect leaders" are rare. We based our analysis on the content of each HRD professional's own account of BLD practice in their organisation, triangulated with the accounts of other managers in the same organisation before selecting them for detailed analysis.

The organisations in which these 17 managers worked were assessed, again, from the initial interview data, to identify the extent to which they reflected unfavourable circumstances. Based on a content analysis of the different accounts used to construct the original organisation case studies (see Bailey and Clarke, 2008) we were able to obtain clear indicators of the relative confusion or disagreement about BLD. Only six individuals from the seventeen managers interviewed met the first criteria and only two met both. However, in 
reviewing the data from phase one, a further case was identified from data collected from a postal questionnaire that was used to test the generalisability of the original interview data. This case also met the above selection criteria, albeit without the additional company data available in the first two cases.

\begin{tabular}{lll}
\hline Less & More & \\
\hline Problem-solving & Innovating in networks/partnerships/market \\
& Handling ambiguity \\
& Lateral thinking \\
& Anticipating the future & Asking difficult questions \\
Complacent & Risk-taking & \\
& Entrepreneurial & Table I. \\
Defensive & Willing to exceed organisational boundaries & Future-oriented \\
Narrow & Confident & Open, demonstrating people are key \\
Managing output/utilisation & Listening, involving, participative & leadership capabilities \\
& Managing the how & \\
& Longer-term approach & Acclimatising people to change \\
\hline
\end{tabular}

Follow up, semi-structured interviews with all three individuals, were used to explore, clarify and validate points about context and activity arising from the original semi-structured interview data or questionnaire. As with the original data collection, the tendency for socially desirable responses was minimised by assuring confidentiality and anonymity and judgemental responses avoided. Each individual case was then content analysed for evidence of political behaviour using standard practices for qualitative data described by Miles and Huberman (1994; Milliken et al., 2003; Harrison, 2002). Political behaviour was assessed by the degree to which these individuals recognised a plurality of interests and influence at work in the formulation and execution of BLD, some active assessment of its impact on the implementation of BLD and their degree of willingness to work, either overtly or covertly with this diversity of interest in order to achieve an outcome which they considered beneficial. The extent to which the resulting outcomes could be described as beneficial to themselves or others was based on a combination of interview data gleaned from across their organisation and/or documentary evidence such as post programme appraisals. The three individuals concerned were given an opportunity to critique/comment on the content of their case. Apart from a few points of detail, none of these observations necessitated substantive revisions.

Each case study below provides background information about the individual, their organisation and how they have succeeded in implementing their interesting, stimulating, and at times, radical ideas about management development and business leadership in unfavourable circumstances.

\section{Javier}

Javier worked for four years as the Training and Development manager in a substantial international engineering consultancy, which at the time of researching, had grown to around 3,000 employees and had a turnover of over $£ 150$ million. Much of this growth had been achieved through mergers and acquisitions, which over time produced an extremely diverse organisation. Overall however, the organisation had a conservative and hierarchical culture. There was considerable commitment to high service levels but a genuine customer focus was hampered by a predisposition to concentrate on technical/product issues. In Javier's view, this 
helped to engender a short-term cost focus and meant that the organisation was in need of a different kind of leadership, one that was capable of generating a longer-term vision about where it was going.

From Javier's perspective this was not fertile ground for BLD. Only two of the main board had any management development themselves and training and development was an easy area for cost reduction. Until Javier's arrival, BLD had taken place on a slow drip feed basis and because of the sise of the organisation, was having very little impact. It is not surprising that Javier initially found that trying to raise the profile of BLD in these circumstances was "like wading through sludge". Despite these unfavourable circumstances he has clearly had a significant impact on leadership development, attributable to a number of activities.

First, by networking with a small group of "like-minded" senior managers he began to extend his power base and to position BLD as a real lever of organisation improvement. Despite the lack of commitment from the board, Javier and his close colleagues tried to ensure that:

the company takes a three to five year view on management development and becomes very robust about pushing people through the whole organisation ... and this includes having a group board development process which will challenge any fixed mindsets that they might have ...

Second, because of the overall lack of support for BLD, Javier recognised the need to work outside of his formal sphere of authority, albeit at some personal risk. For example, with the general intent of building organisational recognition of the need for change, he helped to champion a key customer relationship survey. While overtly interested in the potential training implications, his real motive was to ensure that the critical absence of an effective customer focus was revealed by the survey, as this would enable him to stimulate debate about the need for substantial change.

Third, Javier was able to opportunely "piggyback" legitimate organisational initiatives and then shape them for other purposes. For example, when, in the face of rapidly declining margins the company initiated a restructuring exercise, Javier turned the opportunity to his advantage. Using the need to train the appointees in their new organisational roles, Javier was able to build a case for a much larger development budget than would have otherwise been sanctioned. He also shaped the development process so that it not only equipped this cadre of senior managers with new role capabilities, but also helped to develop a new approach to leadership in the business. He worked closely with the external provider to ensure that contentious issues were surfaced and to involve the main board in the actual programmes. This was not simply so as to demonstrate executive level support but to expose executives to the emerging issues and for them to take some responsibility for the development process. By working in this way he has moved well beyond fulfilling a managerial role in BLD and actively led the leadership development agenda.

Finally, it is apparent that Javier had a real motivation to make a difference to his organisation. He believes leaders need to be able to take risks to do this:

being prepared to say when things are not right, to challenge opinions and not just tow the company line ... be able to develop vision ... where do we need to be in five to ten years time and how do we need to re-organise to get there. To do that requires self-discipline, being able to make the time and to get others to help develop that vision ... 
Clearly, Javier had the discipline to make time for this himself. Sensing that in the future he would need yet more business acumen to further his cause, he completed an MBA and was considering a move to customer relationship management, as he believed that this would provide more opportunity for making a difference to his organisation.

There was evidence that his work was having an impact. He convinced senior management to continue investing in the high profile development programme despite cost pressures. As a result of the first programme, participants initiated a debate about the need for greater involvement in the corporate strategy-making process and individuals were able to pursue this theme in their own business units through their own personal leadership. Some six to 12 months after the programme managers were surveyed about its value to the business; they believed overwhelmingly that it had been influential in building support for the changes in leadership focus that Javier had anticipated. Three quarters of the participants believed it had made real impact on the company.

Javier is certainly working in commonly encountered unfavourable circumstances. He is, however, demonstrating many future oriented leadership characteristics. He is confident enough in his own vision for BLD and has networked with a small number of like-minded senior colleagues to create a legitimate mandate for this. He is comfortable with taking risks, making the best use of opportunities, like that afforded by the restructuring, to help shape organisational activities to his coalition's purposes. He is also taking risks by deliberately using projects such as the customer survey to acclimatise the organisation to change, albeit that such projects do not formally lie within the boundaries of his authority. His success appears to be more readily related to a reliance on these capabilities rather than gaining highlevel management buy-in and financial support.

\section{Felix}

Felix began his career as an aeronautical engineer before moving into Personnel. At the time of writing he was working in a HRD role, first, for one of the organisations major subsidiaries and then later in an international project role. His employer, a globally branded business, is represented in 40 countries and comprises many autonomous businesses with different markets. This diversity was the cause of pressure from investors, calling for the business to justify their broad portfolio and to demonstrate a greater level of synergy from its global operations.

This organisational context created a wide diversity of agendas. It has also created ambiguity about the nature and role of HR/MD and consequently affected the degree of financial support it attracted. There was no clear and formal strategy for BLD across the whole organisation. From Felix's perspective:

I don't think people would say that leadership isn't important, but there isn't necessarily a belief that good business leadership is developed through what people would see as normal development processes.

This lack of understanding about the nature and potential of BLD became an issue when Felix was asked, as a result of the push for greater global synergies, to take on a project to create a corporate approach to succession planning for senior executives. On the one hand there was a desire to institute greater levels of consistency, on the other, a strong tradition of 
individual development and local autonomy in BLD. Felix anticipated the imposition of a top-down approach resulting in great resentment:

Maintaining a balance between top-down inspired activities and bottom-up individualised development is important. We need to be able to hold back top-down initiatives to enable pockets of good practice to occur if development is to take place in which people develop a sense of their own ability to influence things.

The distinguishing feature of Felix's leadership approach was his ability to network; building relationships that allowed him to read the diverse agendas around him, noting potential sources of resistance and leveraging mutual interests in pursuit of good organisational causes. In this example, his understanding of these competing agendas helped him to arrive at a workable solution. For example, his skill was critical in identifying supporters for his approach:

What we were doing was taking a "pockets of good practice" approach ... here we are with a big non-homogenous organization, and my approach was to establish some development principles in a number of places in the business. Actually I couldn't care less where those places were, so let's go with where the energy is to do it. That could be driven by a number of things - a business unit head who just believed that this was the way to do it or in the case of Europe, it was business-driven because of significant growth and real concern over the capability of the people to respond (emphasis added).

Thus by networking extensively and by understanding "where the energy is to do it", Felix was able to build a groundswell of support for an approach to BLD based on common principles without having to rely on unacceptable levels of top-down policy.

This skill was particularly important in managing upwards too. Like Javier, Felix was happy to take some risks with his solution but recognised that this "pockets" approach appealed to his line manager, the HR director who "didn't want to rock the boat ... he was quite a political player, and so it was quite easy to persuade him to go where there was already a few supporters". On the other hand, the solution was somewhat at odds with the Chief Executive's preferred approach and because of that, Felix took a risk in deciding to delay involving him:

One of the obvious routes was to go to the Chief Executive, particularly given that he was under some pressure from his boss to do some of this [top-down] stuff, and say "this is the process we are following, please endorse this". So there was some stealth in deciding not to go down that route. Using the "pockets" route instead I was able to delay the approach to him until the principles had been established and their effectiveness proved so that we didn't have to resort to a top-down approach that might alienate people.

This approach to the succession planning project again reflected sensitivity to the range of organisation circumstances and an ability to read and take account of others views. It involved getting the senior groups in each region to identify the critical roles and posts and thereby achieve some clarity about how their business worked, who the company was most dependent upon and by implication which roles and people required attention. Formal meetings took place to talk about employees potential and progression, but this was combined with a more informal and flexible mechanism of determining development that enabled a swift response when things needed to be done immediately. The approach was effective 
because once again Felix had been able to identify why it was in the interests of key players to make it work.

Like the other individuals in the case studies, Felix's approach to this project was underpinned by personal clarity about the nature of leadership development:

It's quite possible that in the future individuals will want the power to tailor-make their relationship with their employers - for example working from home. Businesses are probably happy to start doing this but will want something in return - employees who are competent and capable in what they are doing. This means that the individual will need to take responsibility for their own development. Development has been corporate-sponsored but is now becoming more individual-focused. This means that BLD strategy will need to focus on matching individuals to opportunities. People will want good projects and good jobs as that's where the learning, development and building capabilities will come from.

Whether or not these ideas will prove to be correct is of course open to debate, one in which Felix was happy to engage. However he had a clear vision for development and combined with his relationship building capabilities, was able to lead effectively in addressing BLD issues. He was confident to take personal risks in the way, for example, he positioned his succession planning project, delaying the chief executive's formal involvement in order to build support from within the business. This was an unusual decision given that "gaining senior management commitment" is usually the first prescribed port of call in managing change, but nevertheless, one that actually helped secure agreement to his plan. The ambiguity and uncertainty of this complex set of organisational relationships appeared to be no barrier to the effectiveness of his activities.

The project was successfully implemented with a high degree of organisation buy-in, without the need for inappropriate levels of central policy. This was achieved in no small measure, through Felix's leadership. After working for the company for two years, Felix was ready for his next leadership challenge and took up an HR director's role in a high profile and growing business.

\section{Christian}

At the time of the research, Christian worked as an HRD director with new product development responsibilities for a UK-based financial software company for which he had worked for six years, initially as quality manager.

With the emergence of financial e-business solutions the company was under considerable pressure to improve its new product development (NPD) process. However, as a relatively small independent player the company could not hope to compete with the major software houses in terms of R\&D. The organisation's strategy was therefore to spot trends early in their cycle and then respond quickly to these or as Christian described "spotting the waves and surfing them while they last", - "we can't create the waves we can only surf them". In theory, this approach would play to the strengths of a relatively small organisation but would require agile processes and nimble leadership. However, over the last few years in an effort to buoy up the profit margin much of the people development work to sustain this agility had been neglected. Functional silos had developed to protect "turf" and because of the directive and autocratic approach taken by the chief executive, risk taking and change had been reduced to a minimum. In this environment BLD had not been seen as a priority, and most 
development investment was simply viewed as a cost by the dominant chief executive and finance director coalition.

Despite these unfavourable circumstances Christian saw the potential for BLD to have a positive impact on the organisation. He tried many ways of convincing his colleagues as to its value but with little success and with only a limited budget he settled on an unconventional approach. His plan was to seed the organisation with capable individuals who could influence change from the bottom-up by:

developing a cadre of people who have a level of knowledge and a level of understanding, ... [and] ... the internal environment that allows them to push the status quo, to change the business, ... so it challenges the traditional hierarchy of the organisation - because the internal cadre will basically be leading and developing organisational change.

Such an approach is at odds with much conventional thinking about initiating organisation change but reflects a "pocket of good practice" approach, similar to that pursued by Felix.

Given this strategy, the need for immediate action and limited financial backing, Christian was highly selective about who he involved by focussing on those who clearly had the talent, ambition and energy to make things happen. First, he selected a small number of like minded senior colleagues to receive high quality external leadership development who, once back in the organisation, would be encouraged to act as role models of change leadership. Second, he established a middle management development programme overtly aimed at improving cross organisation working but which, under Christian's leadership, had other ambitions. In order to initiate change from below, the programme involved a strong personal development focus to equip the managers with the confidence that they could make things happen despite the organisation. In attempting to catalyse this change he needed managers who could:

get out of their mindsets, let go of the past and employ inductive reasoning.

The success of this bottom-up strategy was very much dependent on Christian's personal leadership. Based on interview data collected from participants on the programme it is clear that he put into practice his own views about the nature of leadership:

I think people with charisma tend to be able to set ... [a] ... vision and really sell the vision, they tend to be able to motivate people without putting quite as much effort into it and they're able to make people feel a lot more special than the old typical command and control leaders. To create a nimble organization, you need leaders with that element of charisma.

In this way he personally led the middle management development process and mentored and coached key individuals as they tried to implement the ideas from the programme. He was able to build a sense of camaraderie and cohesion amongst the group that gave them confidence. He was also careful to protect this emerging confidence from what he saw as "outside interference" nurturing their action learning projects until they were sufficiently established to withstand criticism and scrutiny.

Like the other two examples above, Christian was not always upfront about some of his activities, as he believed they would not gain open support. For example, certain initiatives were disguised under non-training budget codes. Similarly, he was not explicit about his motive to get non-executive directors to become mentors for senior managers. In reality, as 
well as helping his senior managers, he hoped the process would provide greater legitimacy for development activities.

Also like Javier and Felix, Christian was an excellent networker and relationship builder, gathering support for his actions in an often-hostile environment. Above all else perhaps, he demonstrated a real willingness to challenge the status quo and take personal risks. In eschewing conventional approaches to BLD by building from the bottom-up and being highly selective, he was nevertheless able to produce tangible results. The carefully selected senior managers who attended the external leadership programme were able to tackle change management projects that had, as one of them described, "been put in the too hard basket". These projects enabled the company to reduce costs and streamline customer relationship processes with the effect of improving customer relationships and decreasing complaints dramatically.

As for the ultimate goal of improving NPD, Christian's actions came too late. The company was taken over and asset stripped. Christian, however, had made a difference. Whilst the chief executive and finance director were not employed by the new owner, Christian was retained to help with the merger.

\section{Emerging themes}

These three individuals were selected because, in their approach to BLD, they reflected many of the attributes required for future business leadership - qualities of future thinking, risk taking, and so on. They were also selected on the basis that they would provide insight about the broad personal dispositions that enable managers to make progress in situations where there was confusion or lack of agreement about the strategic value of BLD. In all three cases the managers were clearly conscious about the importance of power in assessing and working with the plurality of interests at work in BLD. This included an ability to read competing and potentially beneficial organisational agendas and to use these as a basis for building support. For example, Felix used the discovery of different business needs from around the company to build an agenda for his actions. An understanding of key agendas also meant that sometimes the managers felt it necessary to be covert about their activities in the long-term interests of the organisation. These practices, such as Christian disguising expenditure under different budget codes, are of course in direct contravention to many popular ideas about openness and collaboration in contemporary organisations (see for example, Cloke and Goldsmith, 2002).

The use of power and politics as a process for the reconciliation of competing interests was evident in three ways: in the approach to relationship management, challenge and critique and in building change from the bottom-up.

\section{Relationship management}

Each individual clearly placed a premium on relationship building and networking, across, up and down his or her respective organisations. This provided a rich source of power and social capital for each manager (Murphy and Southey, 2003; Collins and Clark, 2003). Whether this was Christian using non-executive directors to promote his cause or Javier working on customer relationship activities, they did not appear to feel constrained by hierarchy or their formal responsibilities in the way they formed these relationships. For example, Javier and Felix were able to get the support of their sponsor/manager and a few other key influencers, but Christian built the same support amongst his peers without the formal backing of his boss. In these ways, each individual ensured the relevance of their agendas and goals and that they 
were balanced with what was perceived to be broader organisational needs, even though in many respects their ideas clashed with the dominant priorities at that time. A more conventional approach may have been to either substantially reshape their initiative to gain greater senior management acceptability, and thus reduce its business impact, or, to simply have dropped the idea altogether in favour of easier pickings.

\section{Challenge and critique}

In contrast to a more traditional managerial approach to BLD, each of the three individuals was proactive in challenging and questioning their organisation's strategy (or lack of), but also had clear well thought out alternatives. In this way each manager demonstrated a certain level of organisational irreverence (Butcher and Atkinson, 2001); a preparedness to critique and work counter to conventional norms and behaviours. For example, Christian deliberately seeded change lower down the organisation to challenge his organisation's approach to hierarchy. Irreverence was also evident in the way Felix held back the pressure for top-down initiatives and built a power base from the bottom-up and in the way Javier surfaced contentious issues in his development programme in order to stimulate critical debate. This irreverence echoes Legge and Exley's (1975) proposition that such deviant innovation can be a source of influence. This is derived from an ability to reframe values or conventions, often by reference to groups or benchmarks "external" to those being influenced such as in the way Javier used data from the customer survey to promote his agenda for BLD.

\section{Building change from the bottom up}

There is now a growing body of literature that promotes the effectiveness of change initiatives inspired by small homogeneous groups located at lower organisational levels. These have been described as "hot groups" (Lipman-Blumen and Leavitt, 1999) or "communities of good practice" (Brown and Duguid, 1991). Such groups may be either formally recognised teams or units or they may simply spring from networks across an organisation. Whatever their form they are characterised by a purpose and intention to innovate, affirm or modify theories in use and act as role models to spread knowledge and new rules for action (Hendry, 1996). This emerging approach to change can be equally if not more effective than traditional top-down approaches (see Hamel, 2000) as it builds on real personal interests and aligns them with live organisational issues.

The three individuals described here worked with a bottom-up approach, building change without explicit senior management approval, either in order to gain support or avoid senior management opposition. For example, Felix expressly built his methodology in line with "where the energy is" and resisted the opportunity to use a top-down approach in contravention of conventional best practice change management. Similarly, Christian selected a cadre of middle managers to "initiate change from below" and Javier networked with a small number of "like-minded managers" to implement his vision for BLD.

We defined politics as "those deliberate efforts made by individuals and groups in organisations to use power in the pursuit of their own particular interests" (Butcher and Clarke, 2001, p. 18). This definition suggests a preoccupation with self-serving outcomes, which is not borne out by the cases. It is apparent that each person was motivated by a personal view about leadership and the way their organisation needed to work in the future. In the absence of any coherence from above they created their own vision for the activity. They each displayed a belief that they could make a difference despite the formal opposition often arrayed against them. Nor did they wait for permission or formal support. Rather than rely on formal organisation authority or power they sought and used the opportunity to 
influence the direction of their organisation regardless of their position or context. However, in doing so, each individual appeared to be attempting to balance their individual interests with those of other influential groups, either at senior levels or lower down the organisation.

\section{Points for reflection and action}

To what extent then do these case studies contribute to or contradict existing research in this area? First, although these cases were specifically chosen because they reflected a degree of confusion or disagreement about BLD, we believe that these themes suggest that, at the very least, much best practice advice on leadership development needs to be tempered with an acknowledgement of the degree to which it is subject to competing interests (Burgoyne and Jackson, 1997; Novicevic and Harvey, 2004). This raises questions as to the efficacy of unitary values to be found in much of the HR best practice literature (Caldwell, 2003). Ready and Conger (2003) suggest that the pursuit of sectional interests constitutes one of several pathologies that lead to the death of leadership development activity. Their solution is to develop shared ownership, but in the situations described here, that would have constituted an idealistic aspiration. Instead, embracing the sectional interests at work, to gain at least temporary organisational momentum, proved to be a valuable approach to overcoming the political barriers to effective BLD.

However, when set alongside unitary notions of organising, political processes are seen as illegitimate. Indeed, much of the trio's behaviour was close to the edge of "acceptable" activity and might only be construed as "principled" because the three individuals appeared to have taken care to build a mandate that was justifiable to others. This approach very much supports Buchanan's (1999) notion of a "logic of political action" in which individuals account for their actions according to the extent to which they can be considered to contribute to organisational outcomes, maintain their reputation and are able to justify these actions to themselves and others. There was a candid honesty about their motives to be stealthy or covert in their actions. Indeed, the managers did not seek to explain their behaviour according to unitary notions of "best practice" (Francis, 2002), but actually embraced the plurality of interests at play in their companies. These examples suggest that if such processes can be legitimated by association with organisational outcomes, they can provide scope for conflicting perceptions and dissent to be aired in the interests of organisational learning rather than simply the pursuit of sectional interests (Coopey and Burgoyne, 2000). For example, Felix, by working behind the scenes with his development provider, was able to raise difficult issues in a formal learning environment attended by board members. This approach is redolent of Burgoyne and Jackson's (1997) "arena thesis" in which management learning is seen as a domain in which "conflicting purposes and values ... meet to be refined, reconciled or proliferated" (Burgoyne and Jackson, 1997, p. 61), and Reynolds' (2000, p. 71) notion of communities as a "politics of difference".

The cases also shed light on other types of behaviour that may enable HRD professionals to overcome the criticisms, evident in the literature, of insufficient influence, poor innovation and lack of integration and linkage with the business. For example, Fulmer and Wagner (1999) highlight the importance of ensuring leadership development attracts high level support and Murphy and Southey (2003) the positive impact of a legitimate strategic role for HR. Whilst these of course have value, this research demonstrates that it is by no means critical, and may at times be counter-productive. In unfavourable political and financial circumstances considerable progress was made through bottom-up informal "pockets of good practice". The three individuals initiated change irrespective of direct senior management support, and in Felix's case deliberately eschewed that support in order to make progress. 
They demonstrated varying degrees of organisational irreverence in order to overcome the barriers as they saw them.

These tactics are also reflective of a pluralist perspective that acknowledges a diversity of, and value in, competing interests. This point of departure from mainstream unitarist HR best practice (Caldwell, 2003) may provide HRD professionals struggling to gain recognition of their value, some glimpses of alternative approaches for making an organisational difference. In demonstrating leadership by linking their activities to key issues, by developing their own views about BLD and by an astute reading and managing of political activity, the three individuals were able to largely overcome the "Catch 22" situations preventing real organisational change that are, according to our phase one research, so commonly experienced by individuals in HR/MD roles. In this sense, the findings here offer a refinement to contemporary blanket best practice leadership development advice and supports Truss's (2001) conclusion that the traditional functional approach to HR may be redundant in the face of (political) organisational realities.

As these findings are based on only three cases, and our intention to stimulate debate about the role of HRD professionals, care should be exercised in generalising results. However they do suggest several potentially fruitful research directions. For example, In the light of the increasing plurality of organisation forms and interests (Denis et al., 2001), should the HR profession embrace the idea of constructive political values? In order to stimulate innovation, should organisation irreverence become an accepted value in the HR canon? In these cases, bottom-up processes of change were effective. Is the tension between managerialist top-down approaches and irreverent bottom-up change irreconcilable, or just a passing phase as organisations adjust to new models of working that are more appropriate to the new economy? What is an appropriate model for the role and requirements of HR/MD in the conditions of today's turbulent and fragmented business environments? Should they set or simply implement the BLD agenda? Are HR/MD professionals equipped for taking this potentially strategic role?

While such questions will take time to research, our findings also provide immediate points of personal reflection for HRD specialists. To this end, following Francis (2002), we hope that they stimulate consideration of competing "world views" about how and why change is implemented. With this in mind the following questions are designed to compliment the case studies and encourage personal learning and debate about the role and value of HR in the enactment of BLD:

- How well would I rate myself against the leadership capabilities highlighted as being important in the future?

- Do I have a clear vision for BLD in my organisation?

- How well does that fit with the prevailing culture of my organisation?

- How unfavourable are the circumstances for instituting effective BLD in my organisation? What are they?

- How well am I able to "read" the political landscape?

- How good are my networking and relationship building skills?

- How prepared am I to work with others views about what is considered important?

- How effective am I at creating an organisation mandate for my ideas?

- To what extent am I prepared to take personal risks to challenge the current situation?

- To what extent am I prepared to step outside my formal responsibilities to seek opportunities to influence? 
In conclusion, we have sought to explore a key issue critical to understanding the apparent difficulty in applying and benefiting from best practice leadership development advice so as to inform innovative future practice - how leaders in HR/MD are able to create effective BLD and to make a difference personally despite unfavourable circumstances of extreme financial and political difficulty. These substantial and intractable "Catch 22" problems are not likely to be resolved by simple single solutions or any silver bullets. The issues are bound up in the complexity and dynamics of contemporary organisations. However our cases suggest that individual leadership of business leadership development may be one way forward in the short-term. We asked whether best practice leadership development advice was fundamentally flawed or simply in need of refinement. To the extent that advice is premised on a unitary perspective on organisations and ignores the political capital at stake in the business leadership agenda, then our research of practice would seriously question the likelihood of ever closing the gap through adherence to blanket principles. However, accepting a pluralistic standpoint allows practitioners to critically evaluate and selectively apply these ideas in their specific organisational context. Ultimately, in our view, these cases suggest that in the face of unfavourable organisational circumstances the leadership capabilities (cognitive, relational and political) of development professionals will inevitably be a critical factor in their success.

\section{References}

Ammeter, A., Douglas, C., Gardner, W., Hochwater, W., Ferris, G. (2002), "Toward a political theory of leadership", The Leadership Quarterly, Vol. 13 No.6, pp.751-96.

Axel, H. (1999), "Developing leaders", HR Executive Review, Vol. 7 No.1, pp.1-19.

Bailey, C., Clarke, M. (2008), "Aligning leadership development: the value of discrimination", Journal of Management Development, (forthcoming).

Bhaskar, R. (1974), A Realist Theory of Science, Leeds Books, Leeds.

Blaikie, N. (1993), Approaches to Social Enquiry, Polity Press, Cambridge.

Brown, J., Duguid, P. (1991), "Organization learning and communities of practice: toward a unified view of working, learning, and innovation", Organizational Science, Vol. 2 No.1, pp.40-57.

Buchanan, D. (1999), "The logic of political action: an experiment with the epistemology of the particular", British Journal of Management, Vol. 10 No.3, pp.S73-S88.

Buchanan, D., Badham, R. (1999), Change, Power and Politics: Winning the Turf Game, Sage, London, .

Burgoyne, M., Jackson, B. (1997), "The arena thesis: management development as a pluralistic meeting point", in Burgoyne, M., Reynolds, M. (Eds), Management Learning, Sage, London, pp.54-70.

Butcher, D., Atkinson, S. (2001), "Stealth, secrecy and subversion: the language of change", Journal of Organizational Change Management, Vol. 14 No.6, pp.554-69.

Butcher, D., Clarke, M. (2001), Smart Management: Using Politics in Organizations, Palgrave, Basingstoke.

Butcher, D., Clarke, M. (2002), "Organization politics, the cornerstone of organization democracy", Organization Dynamics, Vol. 31 No.1, pp.35-46.

Cairns, H. (1997), "Study of current practice in assessing the impact of management development in international organisations", paper presented at the UNICON Conference, 
Creating the Future of International Executive Development Together: A Visioning Process, Lausanne, 5-7 April.

Caldwell, R. (2003), "The changing roles of personnel managers: old ambiguities, new certainties", Journal of Management Studies, Vol. 40 No.4, pp.983-1004.

Chia, R. (2002), "The production of management knowledge: philosophical underpinnings of research design", in Partington, D. (Eds), Essential Skills for Management Research, Sage, London, pp.1-19.

Clarke, M., Bailey, C. (2002), "Leadership development - creating innovative future development", paper presented at the 1st EAISM Conference on Leadership Research, Oxford, December.

Clarke, M., Butcher, D., Bailey, C. (2004), "Strategically aligned leadership development", in Storey, J. (Eds),Leadership in Organizations, Routledge, London, pp.271-92.

Cloke, K., Goldsmith, J. (2002), The End of Management and the Rise of Organizational Democracy, Jossey Bass, San Francisco, CA.

Collins, C., Clark, D. (2003), "Strategic human resources practice, top management team networks, and firm performance: the role of human resource practices in creating organizational competitive advantage", Academy of Management Journal, Vol. 46 No.6, pp.740-51.

Conger, J., Xin, K. (2000), "Executive education in the 21st century", Journal of Management Education, Vol. 24 No.No. 1, February, pp.73-100.

Coopey, J. (1995), "Managerial culture and the stillbirth of organisational commitment", Human Resource Management Journal, Vol. 5 No.3, pp.56-76.

Coopey, J., Burgoyne, J. (2000), "Politics and organizational learning", Journal of Management Studies, Vol. 37 No.6, pp.869-85.

Denis, J., Lamothe, L., Langley, A. (2001), "The dynamics of collective leadership and strategic change in pluralistic organisations", Academy of Management Journal, Vol. 44 No.4, pp.809-37.

Fairclough, N. (2005), "Discourse analysis in organization studies: the case for critical realism", Organization Studies, Vol. 26 No.6, pp.915-39.

Ferris, G., Judge, T. (1991), "Personnel/human resources management: a political influence perspective", Journal of Management, Vol. 17 No.2, pp.244-488.

Francis, H. (2002), "The power of talk in HRM based change", Personnel Review, Vol. 31 No.4, pp.432-48.

Fulmer, R., Wagner, S. (1999), "Leadership: lessons from the best", Training and Development, Vol. 53 No.3, pp.28-33.

Galang, M., Ferris, G. (1997), "Human resource department power and influence through symbolic action", Human Relations, Vol. 50 No.11, pp.1403-26.

Gibb, S. (2001), "The taste of human resource management: evidence from employees' views of HRM systems and staff", Employee Relations, Vol. 23 No.4, pp.318-36.

Gratton, L., Hope Hailey, V., Stiles, P., Truss, C. (1999), Strategic Human Resource Management, Oxford University Press, Oxford. 
Guest, D., King, Z. (2004), "Power, innovation and problem solving: the personnel managers' three steps to heaven?", Journal of Management Studies, Vol. 41 No.3, pp.401-23.

Hamel, G. (2000), "Waking up IBM: how a gang of unlikely rebels transformed big blue", Harvard Business Review, Vol. 78 No.4, pp.137-44.

Harrison, A. (2002), "Case study research", in Partington, D. (Eds), Essential Skills for Management Research, Sage, London, pp.158-80.

Hayes, J., Rose-Quirie, A., Allinson, C. (2000), "Senior managers' perceptions of the competencies they require for effective performance: implications for training and development", Personnel Review, Vol. 29 No.1, pp.92-105.

Hendry, C. (1996), "Understanding and creating whole organizational change through learning theory", Human Relations, Vol. 49 No.5, pp.621-41.

House, R., Aditya, R. (1997), "The social scientific study of leadership: quo vadis?", Journal of Management, Vol. 23 No.3, pp.409-73.

Legge, K. (1995), Human Resource Management: Rhetorics and Realities, Macmillan, London.

Legge, K., Exley, M. (1975), "Authority, ambiguity and adaptation: the personnel specialist's dilemma", Industrial Relations Journal, Vol. 6 No.3, pp.51-65.

Lipman-Blumen, J., Leavitt, H. (1999), "Hot groups 'with attitude', a new organizational state of mind", Organizational Dynamics, Vol. 27 No.4, pp.63-74.

Mabey, C. (2002), "Mapping management development practice", Journal of Management Studies, Vol. 39 No.8, pp.1139-60.

Mabey, C. (2005), Management Development Works: The Evidence. Executive Summary, Chartered Management Institute, London, January.

Mabey, C., Thomson, A. (2000), "Management development in the UK: a provider and participant perspective", International Journal of Training and Development, Vol. 4 No.4, pp.272-86.

Meldrum, M., Atkinson, S. (1998), "Is management development fulfilling its organisational role?", Management Decision, Vol. 36 No.8, pp.528-32.

Miles, M., Huberman, M. (1994), Qualitative Data Analysis, Sage Publications, Thousand Oaks, CA.

Milliken, F., Morrison, E., Hewlin, P. (2003), "An exploratory study of employees silence: issues that employees don't communicate upward and why", Journal of Management Studies, Vol. 40 No.6, pp.1454-76.

Murphy, D., Southey, G. (2003), "High performance work practices, perceived determinants of adoption and the role of the HR practitioner", Personnel Review, Vol. 32 No.1/2, pp.73-92.

Novicevic, M., Harvey, M. (2004), "The political role of corporate human resource management in strategic global leadership development", The Leadership Quarterly, Vol. 15 No.4, pp.569-88.

Partington, D. (2002), "Grounded theory", in Partington, D. (Eds), Essential Skills for Management Research, Sage, London, pp.136-57.

Perrewe, P., Ferris, G., Frink, D., Anthony, W. (2000), "Political skill: an antidote for workplace stressors", Academy of Management Review, Vol. 14 No.3, pp.115-25. 
Ray, T., Clegg, S., Gordon, R. (2004), "A new look at dispersed leadership: power, knowledge and context", in Storey, J. (Eds), Leadership in Organizations, Routledge, London, pp.319-36.

Ready, D., Conger, J. (2003), "Why leadership development efforts fail", MIT Sloan Management Review, Vol. 44 No.3, pp.83-8.

Reynolds, M. (2000), "Bright lights and pastoral idyll", Management Learning, Vol. 31 No.1, pp.67-81.

Santos, A., Stuart, M. (2003), "Employee perceptions and their influence on training effectiveness", Human Resource Management Journal, Vol. 13 No.1, pp.27-45.

Sheehan, C. (2005), "A model for HRM strategic integration", Personnel Review, Vol. 34 No.2, pp.192-209.

Skinner, D., Mabey, C. (1997), "Managers' perceptions of strategic HR change", Personnel Review, Vol. 26 No.6, pp.467-84.

Stone, B. (1997), Confronting Company Politics, Palgrave, Basingstoke.

Sung, J., Quinn, M. (2005), CIPD Annual Survey Report - Training and Development, CIPD, London, .

Swan, J., Scarborough, H., Robertson, M. (2002), "The construction of communities of practice in the management of innovation", Management Learning, Vol. 33 No.4, pp.477-96.

Tate, W. (2004), "Linking development with business", in Storey, J. (Eds),Leadership in Organizations, Routledge, London, pp.293-318.

Truss, C. (2001), "Complexities and controversies in linking HRM with organizational outcomes", Journal of Management Studies, Vol. 38 No.8, pp.1121-49.

Zenger, J., Ulrich, D., Smallwood, N. (2000), "The new leadership development", Training and Development, Vol. 54 No.3, pp.22-7. 